\title{
NATURAL VENTILATION IN OLD ISLAMIC HOUSES THE STUDY OF COURTYARD IN OLD CAIRO
}

\section{Case Study: Zeinb Khatoun House}

\begin{tabular}{ccc}
\hline Gihan Mossad & Hussein Ezzat & Nada Talaat \\
Professor of Architecture \& Urban & Professor of Interior Design, & Teaching Assistant of Architecture, \\
Design, Arab Academy for & Faculty of Fine Arts, Alexandria & Arab Academy for Science, \\
Science, Technology and & Universty, & Technology and Maritime \\
Maritime Transport, Alexandria, & & Transportm, Alexandria, \\
\hline
\end{tabular}

\begin{abstract}
Cairo; the capital of Egypt, is a rich architectural environment with long history extending over 70,000 years. The rich history is still educating and informing knowledge in all fields of science. An important part of this history is the Islamic era and its vibrant architecture. This research studies the architecture of houses in old Cairo and focuses mainly on their courtyards. Courtyards in old houses served many purposes; social, religious and environmental factors. Egypt has been confronted with an escalating energy demand due to the gradual rise in the use of mechanical ventilation associated with loss in natural ventilation design in houses. This paper aims at learning from the past to achieve a sustainable built environment by understanding the necessity of passive ventilation strategies and how courtyards inform it. This is achieved through inductive methods such as literature review represented in the first part and analytical method through the application of passive ventilation in an old courtyard Islamic house.
\end{abstract}

Keywords: Courtyard; Passive cooling; Islamic houses , natural ventilation .

\section{Introduction}

Cooling is the transfer of energy from a space or from the air, to a space, in order to accomplish a lower temperature than that of the natural surroundings. In recent years, the use of air conditioning systems to control the temperature, moisture content, circulation and purity of the air within a space, has increasing in order to achieve the thermal comfort

effect for the occupants. The shortage of conventional energy sources and

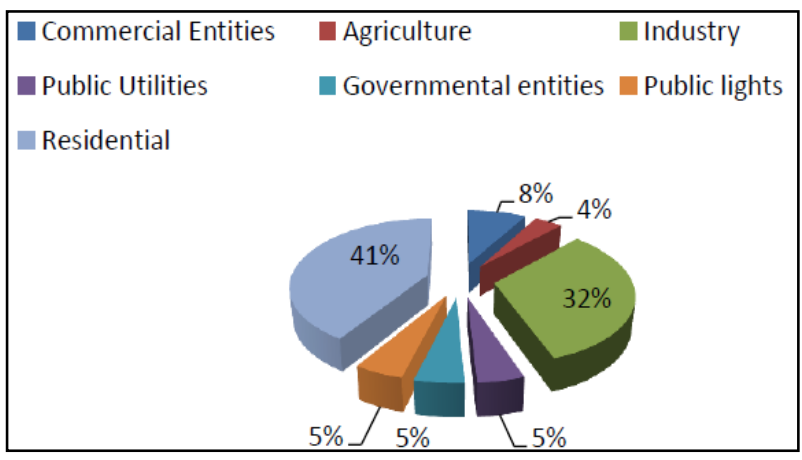

Figure 1 Pie chart that shows the energy consumption in Egypt 2010/2011. Source: (Hanna, 2013)Edited by author escalating energy costs have become an obstacle that needed to be reviewed in the general design and the development of new technologies for achieving this comfort. The following figure represents the energy consumption in Egypt and demonstrates that the residential sector is the most energy consuming by a percentage of $41 \%$ : (Hanna, 2013) (Figure1).

Thus, the use of renewable sources of energy such as the sun and the wind to provide cooling, lighting and ventilation become necessary in nowadays. Passive cooling means improve indoor air quality and provide more comfortable environmental impacts. There are many types of passive cooling strategies that can be implemented for hot arid regions such as Cairo, Egypt. Design strategies that minimize the need for mechanical cooling include strategies to reduce the solar radiation such as the selection of proper 
orientation and the plan shape. Other strategies to reduce the heat gain by analyzing the thermal mass, the shading elements, water and landscaping elements and the openings characteristics. Enhancing the natural ventilation by using wind catchers and by analyzing the single sided, cross ventilation and stack ventilation is considered one of the main strategies of passive cooling.

Passive cooling strategies were used throughout history in Egypt and other countries. The interior courtyard was an essential element for the implementation of passive cooling. In early Pharonic houses, the courtyard appeared and was necessary. It became more important as we arrive to the Islamic Era where it represented the identity of most houses. It differed in its shape, orientation and area but it served different purposes such as the religious and social needs. However, the essential purpose was to avoid the sever temperature of the hot arid climate of Cairo.

\section{Defining natural ventilation}

Ventilation is the process of supplying or removing air by natural or mechanical means to or from a space. The key design of good natural ventilation is the wind. It can increase the thermal comfort and the indoor air quality for users in different interior spaces. In addition, it reduces the use of active HVAC system. Initially, air movement is a result of low and high pressure produced in buildings when positioning inlets and outlets to move the air from high pressure zone to lower ones (West, October 2000).

Natural ventilation is used in interior spaces to meet three main objectives; :health ventilation: to provide good internal air quality to users, to remove odors,pollutants and to limit the radon concentration in the air, comfort ventilation: for cooling the human body, where the air flow passing by the skin increases the evaporation rate from the skin. When the air temperature is higher than the skin, the body is warmed by the heat convection. However, the air velocity increases the evaporation of moisture and by consequence the cooling effect of the body and structural ventilation: the cooling effect that is achieved by cooling the building elements when the indoor air temperature is higher than the outdoor air temperature. Thus, heavy buildings requires higher ventilation rate to reduce the stored heat by convection (Naga, 1990).

\section{Old courtyard houses}

Historically, the courtyard house typology has been presented through history in Egypt. The historical, social, cultural and architectural aspects of courtyard houses, has been discussed briefly. It has clarified the difference of each period which has influenced the courtyard design. In addition, a comparison between Pharonic houses, Islamic houses and modern houses has concluded the existence of courtyard with its diversity based on several points; its location through the house, the orientation, the form and shape, the diverse reason for using courtyards, its entrance, its relation to the main entrance, its area ratio compared to total area of the house, the material used in construction and finishing, shading devices and projections in the courtyard envelope, landscape and water elements used and its design considering enhancing passive ventilation.

The results demonstrate that with modernization and high density of population, the courtyard has decreased in area and in most of modern houses has disappeared completely. Through history it was a main element in the house design except in middle class and workers houses in the Pharonic period where it existed but wasn't considered a central main element. In Islamic era, it was oriented through East -West axis which considered the best orientation in hot arid region unlike the Pharonic and modern period where it was aligned through North-South axis. It was mostly rectangular in shape but in Mamluk period sometimes it took the square shape due to the land plot where the 
house was built. The importance of using courtyard was essential in the Islamic era due to the environmental awareness and privacy reasons. Direct entrance to courtyard only appeared in modern period where there is more transparency and minimalism in the design. The construction materials used were natural materials such as brick and stone. The best design for ventilation purposes was in Islamic and modern where the awareness for passive design has been formed as shown in the figure below. ( Figure2)

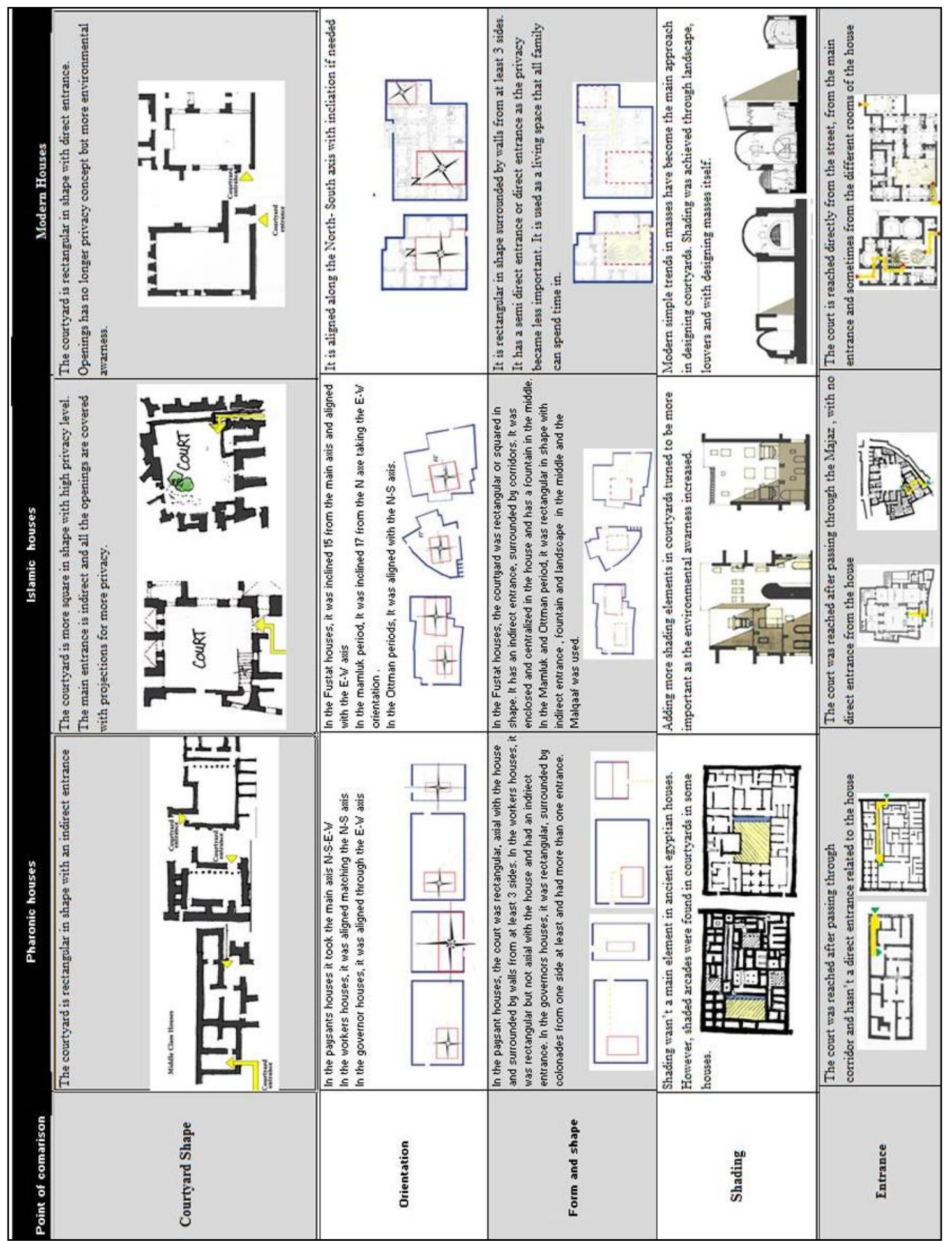

Figure 2 Comparaison between courtyard houses in Cairo representing pharonic houses, Islamic houses and modern houses.Source: researcher 


\section{4.atural ventilation drivers in courtyard}

Wind and buoyancy are the main driven forces for natural ventilation. They create an air exchange between the indoor and outdoor. The ventilation rate relies on the strength and direction of these forces and the resistance of the flow path. The keys to great wind ventilation design are the building orientation and massing, and in addition estimating and setting openings properly for the climate. The natural drivers of ventilation are based upon two main principles. The first one is that the air is derived from higher (positive) pressure zone to a lower (negative) pressure zone. The second principle is that the warm air is less dense than the cold air. This phenomenon is called 'the thermal buoyancy 'or 'stack effect' or 'the chimney effect'. It creates a pressure difference in the air as the reason of rises of warm air because of its density thus, creating air movement. These principles may work separately or combined together as explained in the following. For ventilation design, some climatic data is needed such as the wind rose diagrams. A wind rose diagram is a graphic tool helps to show the distribution of wind and its velocity in a specific place (Camille Allocca, 2003).

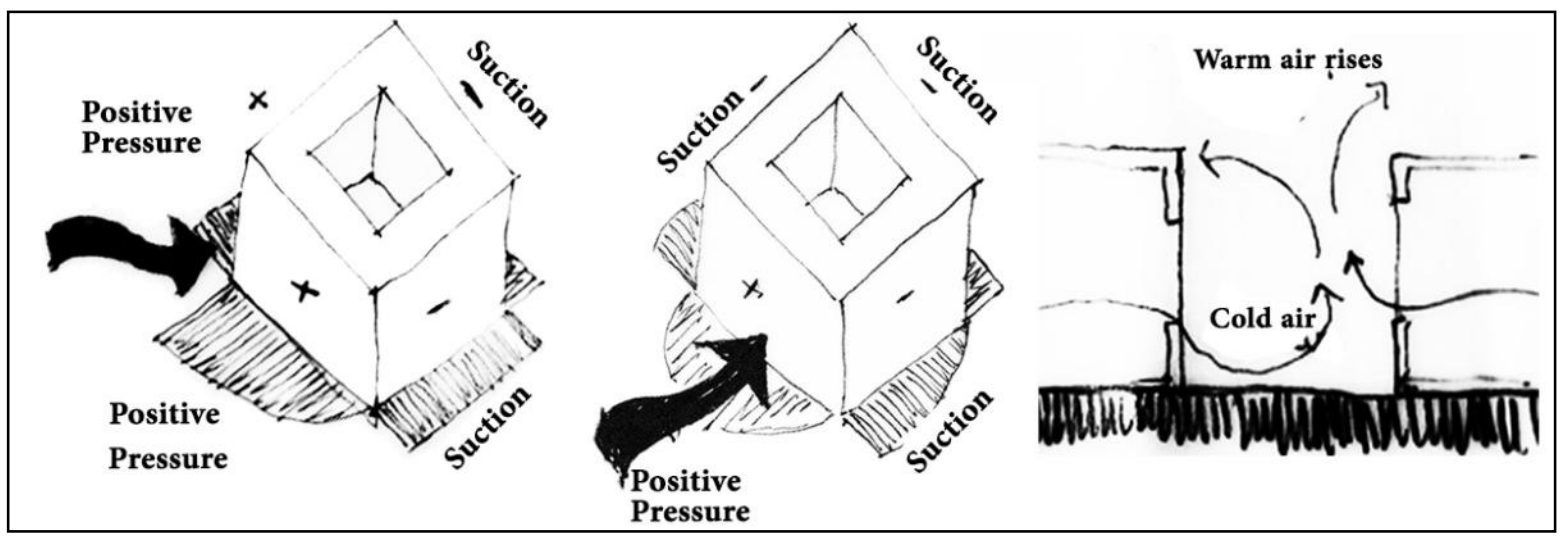

Figure Error! Use the Home tab to apply apple-converted-space to the text that you want to appear here.3 Different strategies for wind ventilation.Source: (Osman, 2011). Edited by researcher

\section{Strategies of natural ventilation}

Natural ventilation can help in improving the thermal comfort in warm and hot climate. This is achievable by following the natural ventilation strategies. The first strategy, the comfort ventilation, is direct cooling effect that a user can feel by increasing the airspeed around the human body producing heat loss and higher evaporation rate to help the occupant feel cooler. The second strategy, the night ventilation, depends on an indirect cooling effect by allowing the thermal mass of a building to be cooled down by the cool night air. This strategy decreases the indoor temperature during the next daytime (Osman, 2011). ( Figure 3)

\section{Techniques of natural ventilation in courtyard}

Three main techniques are used to achieve one of the above strategies in the courtyard design. These techniques explain how the wind is derived into the courtyard and how it is expelled out of it. They are defined as single sided ventilation, cross ventilation and stack ventilation. When integrating two or more of these techniques with a ventilation strategy, a complicated ventilation system is achieved through the building.(Figure 4) 


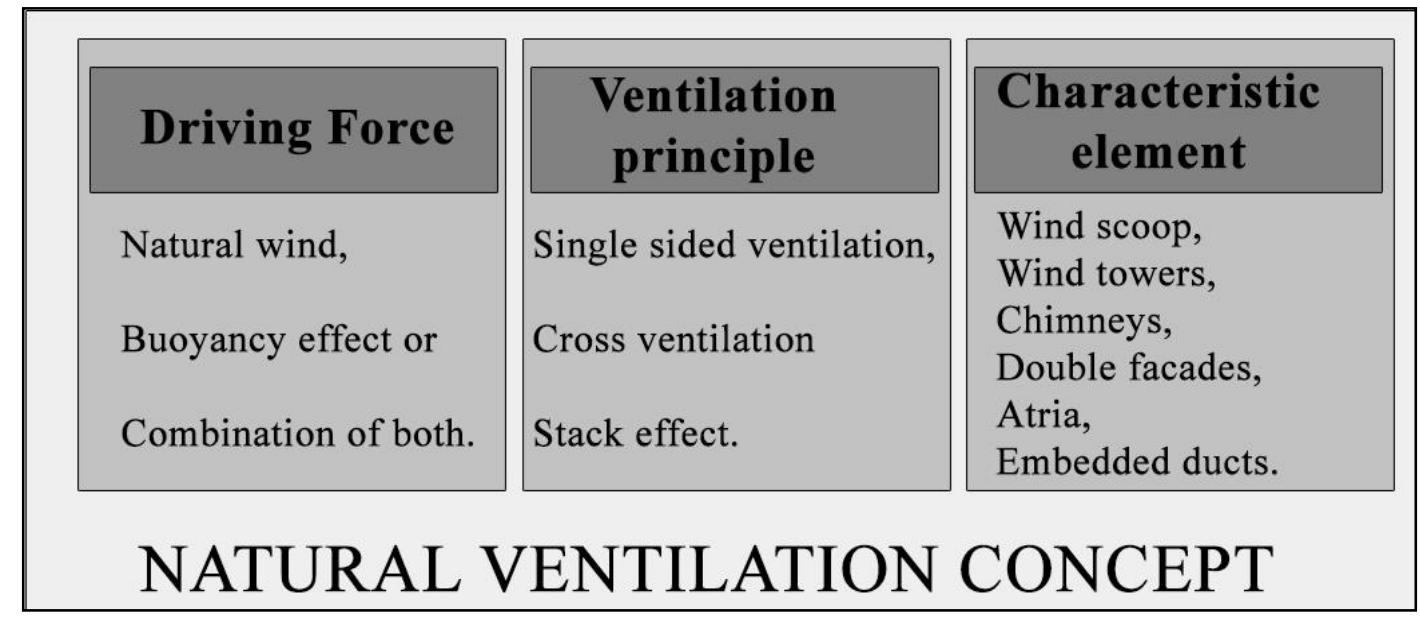

Figure 4 Natural ventilation concepts. Source: reseracher

\section{Technical parameters for natural ventilation}

For natural ventilation design improvement, different parameters affecting air movement in and around the building must be studied. These parameters are classified into three level; macro level which include site landform, heat sinks, urban form, street design for wind orientation, and canyon geometry. The second level intermediate level includes; building adjacency, building arrangement and soft landscape. The third level, the micro level, will be analyzed in details in the following section with concentration on the courtyard shape and proportion.(Figure 5)

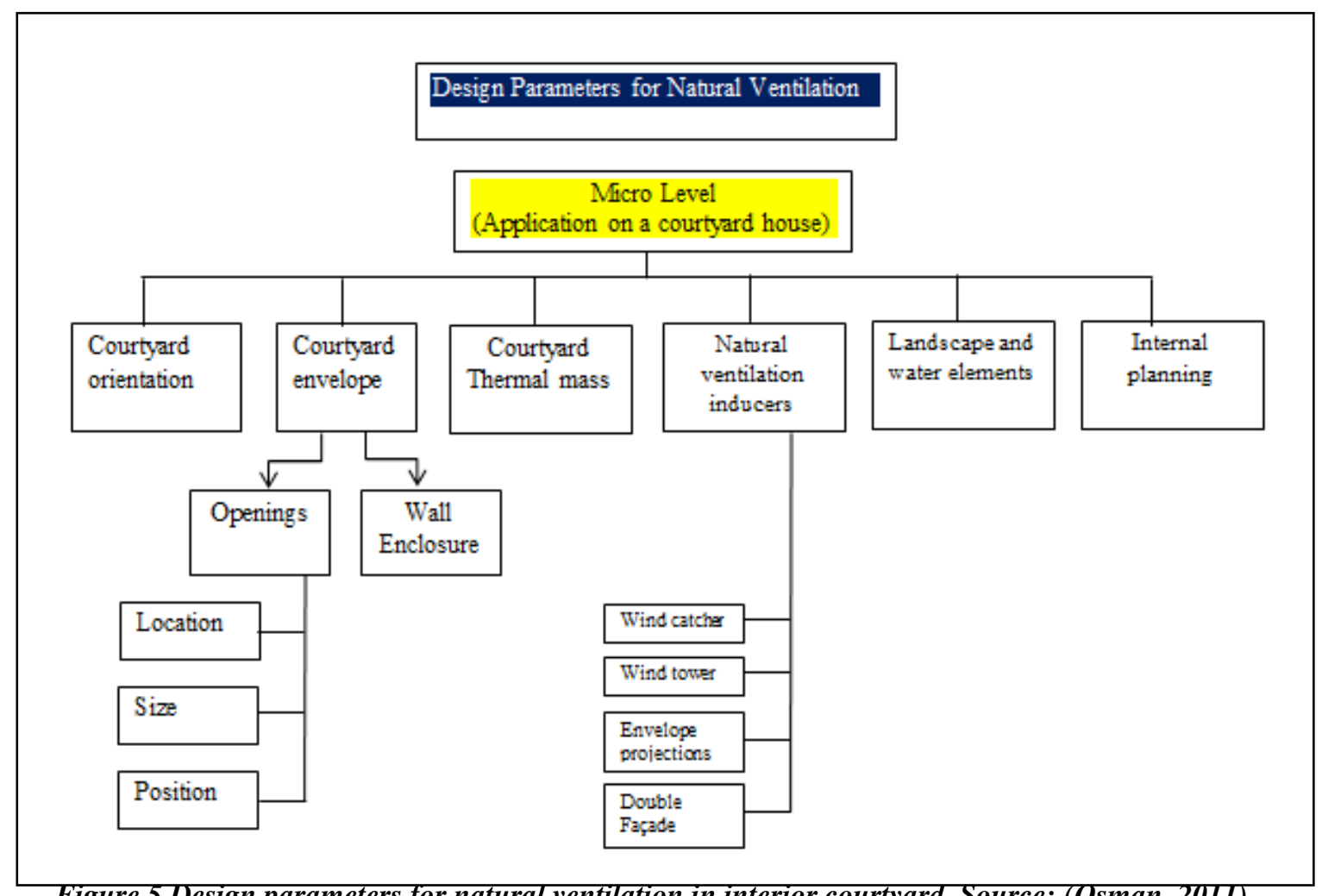

Figure 5 Design parameters for natural ventilation in interior courtyard. Source: (Osman, 2011). Edited by researcher 


\subsection{Technical parameters for natural ventilation in courtyard based on the micro level Courtyard Orientation}

After analyzing the sun chart diagram, the optimum orientation can be estimated in regards to solar radiation. The rectangular plan building can be the starting point in determining the ideal orientation, where the short facades of the building face east and west.In the early morning, the north facade receives the minimum amount of direct sun, with small solar incident angles. Therefore, the north façade openings provide day lighting with minimum heat load to the building. Moreover, the south facade receives the largest amount of sun. However, it is easy to block the large incident angle of summer sun and allow winter sun by using vertical sun shading devices. This is permitted by the sun location; high in summer and lower in winter. (Al-Shaali, 2006)The east and west facades area should be smaller than the north and south facades. Both of the east and west façade are exposed to direct sunlight; the east from morning to noon and the west from noon to sunset. The west façade is considered the worst as it receives the direct sunlight from the hottest time of the day but this can be treatable by attaching elements that decrease the sun exposure such as balconies, arches or open galleries and trees that act as a shading device blocking the low angle sun thus enhancing the microclimate of the building. (Al-Shaali, 2006).

Courtyard Orientation Much of the time, introduction of yard relies on upon the building format. Variables that can decidedly influence the microclimate condition inside the yard are sun area, wind heading, shading execution and sunlight based increase (Bagnied, 2006).

\section{Courtyard envelope}

To accomplish required rate of ventilation, the openings design should be studied. The selection of appropriate element such as window, doors, screens, etc and knowing their potentials is very important in order to apply suitable ventilation technique. For windows design, the placement position (horizontal, vertical or tilted), their placement on the building envelope and their opening system are different design variables according to the required function such as view, daylight, solar gain and ventilation. Screens can be used either for shading and solar protection or for ventilation by selecting the opening size and material. Doors are mainly used for connection between different interior zones but also have a significant role for solar transmittance and for airflow control (Ahmed, 2012).There are many principles for designing opening in courtyards in hot arid regions. Some of these main principles are; Orienting windows to the north and sizing them to correspond the amount of thermal mass in the courtyard and to maximize the winter heat gain, and minimizing summer heat gain by using external shading devices, and by sizing and orienting windows. The proper orientation with the understanding of the time of year helps to receive the appropriate amount of radiation by windows. During summer, windows facing east and west receive net heat gain. For courtyards design, main openings are preferably facing north and south. The southern openings should be shaded by any shading device or by deciduous trees. The heat gain inside a house can be reduced by minimizing the opening sizes on the east and west sides. Openings should be placed in an appropriate position to the prevailing wind direction to allow maximum airflow through the courtyard which achieves evaporative cooling and air exchange through the building. In addition, cross ventilation and stack effect can be inducted into the courtyard by positioning openings in suitable positions. Moreover, outlets should be placed at a high level to exhaust the accumulating hot air 
which is useful for convective cooling. For enhancing comfort ventilation, openings should be placed at the users' level (Paul Gut, 1993). For inserting glass in courtyard, the orientation and the amount of thermal mass must be put in consideration. For brick veneer houses, a ratio of glass area between $20-21 \%$ is preferably. As for double brick houses, this ratio might increase to be between $22-30 \%$.

The different design of courtyards differs in its shape, size and details of the enclosing walls varied among regions and functions. In addition, many elements influenced this enclosure such as the social, cultural economic, environmental conditions, functions and location (Meir, 2000). Wall enclosure refers to all elements that shape the courtyard within the building such as; walls, doors and windows that should be taken in consideration while the design stage. It has a direct influence on the performance of the microclimate condition of the courtyard as it can be controlled by the openings and by the adaptation of the window to wall ratio.

Based on a study by Al-Hemiddi \& Megren (2001), it was found that the cooling effect of courtyard can be optimized by opening all windows that increase the interior natural ventilation rate. However, an insignificant cooling effect was created when all windows were closed (Nasser A Al-Hemiddi, 2001). The courtyard wall enclosure materials, colors and shading devices are other elements to be taken in consideration to enhance the microclimate condition. (Abdulbasit Almhafdy, September 2013)

\section{Courtyard building mass}

At the design stage, many arrangements of the courtyard building must be taken into account in order to ensure appropriate solar radiation in winter for warming and to provide the appropriate amount of shade necessary to reduce heat and the need for cooling in summer. This includes the internal finishing materials and the physical proportions of courtyard form. Therefore, it is recommended to provide properly an amount of solar radiation aiming for an efficient courtyard performance in summer and winter and to avoid designing a courtyard building that generates too many shadows instead of the need of solar radiation or getting a lot of solar radiation when it is not desirable. (Ahmed S. Muhaisen, january 2005) For achieving the appropriate courtyard's proportions to ensure adequate solar heat and thus the energy required to achieve thermal comfort, two ratios should be studied and investigated at different times. The ratio $\mathrm{R} 1$ representing the courtyard's floor perimeter $(\mathrm{P})$ to the height $(\mathrm{H})$. It differs between 1 and 10 in one degree step. The other ratio R2 represents the courtyard elongation, which is a relation between the courtyard width $(\mathrm{W})$ and length(L) . It varies between 0.1 and 1 in one degree step.

Based on a study by (Ahmed S. Muhaisen, january 2005), he investigated the courtyard proportions and its relation with the thermal cooling. A minimum width of courtyard was assumed to be $1 \mathrm{~m}$. The courtyard had a ratio $\mathrm{R} 2$ equal to 0.1 which means its dimensions are $1 \mathrm{~m}$ width and $10 \mathrm{~m}$ length. $\mathrm{R} 1$ for this courtyard was assumed 1 , so the height is $22 \mathrm{~m}$. This courtyard was considered the basic form for his study with an internal area of $484 \mathrm{~m} 2$. The wall surface area was taken as the base for the comparison between the thermal performances of the investigated courtyard form with different proportions. He proved that the annual energy required increases with the increase of the courtyard height but it is not directly proportional to the increase of the courtyard length. He also observed that the amount of energy demand decreases during the $21^{\text {st }}$ July when the design of courtyard became closer to square. He concluded that the energy consumption increases as the shape of courtyard become longer so the solar 
radiation and the heat gain increases which requires more heating and cooling loads. (Enes Yas, aa, 2013 )

\section{Natural ventilation inducers}

Natural ventilation inducers in courtyards are elements integrated with the building design and can be used to enhance the natural ventilation performance in the interior spaces . There are many examples of these elements Some are based upon cross and stack ventilation such as wind scoop, wind tower, chimney, ventilation chamber shafts, wind towers, chimneys, embedded ducts, building envelope projections and double skin facades, embedded ducts. Other are based upon cross, stack and single sided such as double façade, openings in the façade and atriums (Kleiven, 2003).

\section{Landscape and water elements}

Landscaping has an important function in controlling the air movement around buildings for optimum natural ventilation. Vegetation can create areas of higher wind velocities by deflecting winds or funneling air through a narrow passage (Venturi effect). The presence of vegetation at the site also greatly helps in improving the air quality by removing dust particles, absorbing carbon dioxide and producing oxygen into the air. Trees with large foliage mass having trunk bare of branches up to the top level of window, deflect the outdoor wind and promote air motion in the leeward portion of the buildings .

Evaporative cooling is the process of air moving that passes over a wetted surface or a water source such as fountains, river, etc. The water evaporation from surfaces, when hot air passing over, assists in increasing the total humidity level and thus cools the indoor air. This method is used in hot arid regions and it is a direct way of evaporative cooling system. In addition, evaporative cooling can be used in wind catchers, by adding a pump and a fan in the inlet of the duct. The fan catches a greater amount of hot dry air and drags it into the building and it is moisturized by the pump (Yahya Lavafpour, 2011).

\section{Case Study: Zeinb Khatoun Courtyard house}

The traditional courtyard house ( 1400AD) of "Zeinab Khatun" was selected as a case study to analyze its courtyard performance along from the remaining traditional courtyard houses in old Cairo. The house has some characteristics that are common in traditional Cairene courtyard houses such as high thermal mass, marble floors, wooden lattice, shades, and shutter less windows, high ceilings, wall cladding, and dome openings that will be discussed in the following section.

\section{Cairo Weather Data}

The case study house located in Cairo which lies between latitude $26^{\circ} 50^{\prime} \mathrm{N}$ to $30^{\circ}$ $45^{\prime} \mathrm{N}$.It is in a hot arid climate since the moderating existence of water surfaces concentrated on the two blanks of the Nile. of characterized by high diurnal temperature variations and sparse rain fall ( group B according to Koppen classification). It lies in the sub group BWh, arid or desert with hot climate. (Mohamed el Nabawi, 2013 August 26/28)There is an overheating period for 8 months with temperature reaching $42^{\circ} \mathrm{C}$ in the shade. The outdoor design temperature for Cairo is $38.5^{\circ} \mathrm{C}$. The winter climate in Cairo is relatively cold, moist and rainy from December to February. However, it is hot, dry and rainless in summer from June to August. As for the spring from March to May, there is the desert depression or the Khamasin which is described as quite strong, hot and dry winds often laden with dust. The climate is moderate in the autumn from September to November. (Wael Sheta, 2010) The mean average temperatures of Cairo as well as relative humidity profile and wind speed are 
presented in the following figures. The temperature reaches its maximum in June and could get $45^{\circ}$. The humidity is below $40 \%$ most of the year. The common wind is most out of the North $29 \%$, North West $18 \%$ south east $2 \%$ and south $4 \%$. The speed average varies between $3 \mathrm{~m} / \mathrm{sec}$ and $5 \mathrm{~m} / \mathrm{sec}$ in autumn while in spring it can reach $7 \mathrm{~m} / \mathrm{sec}$. (Figure 6-7)

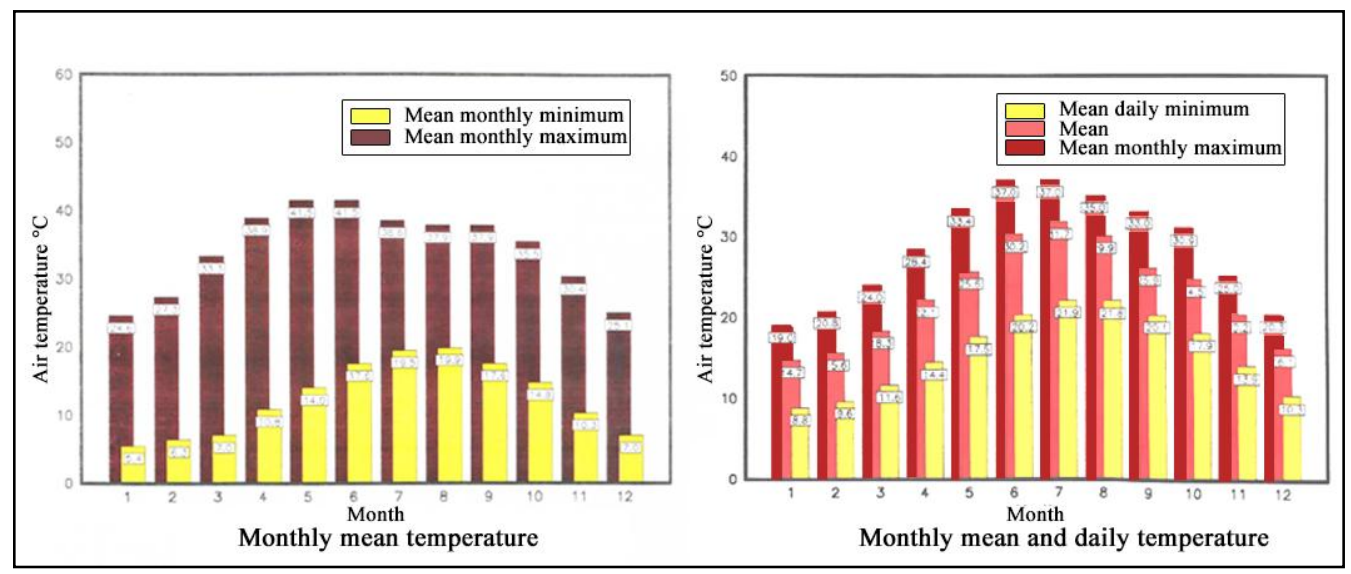

Figure 6 Cairo climatic graphs showing monthly and daily temperature. Source: (NAGA, 1990)

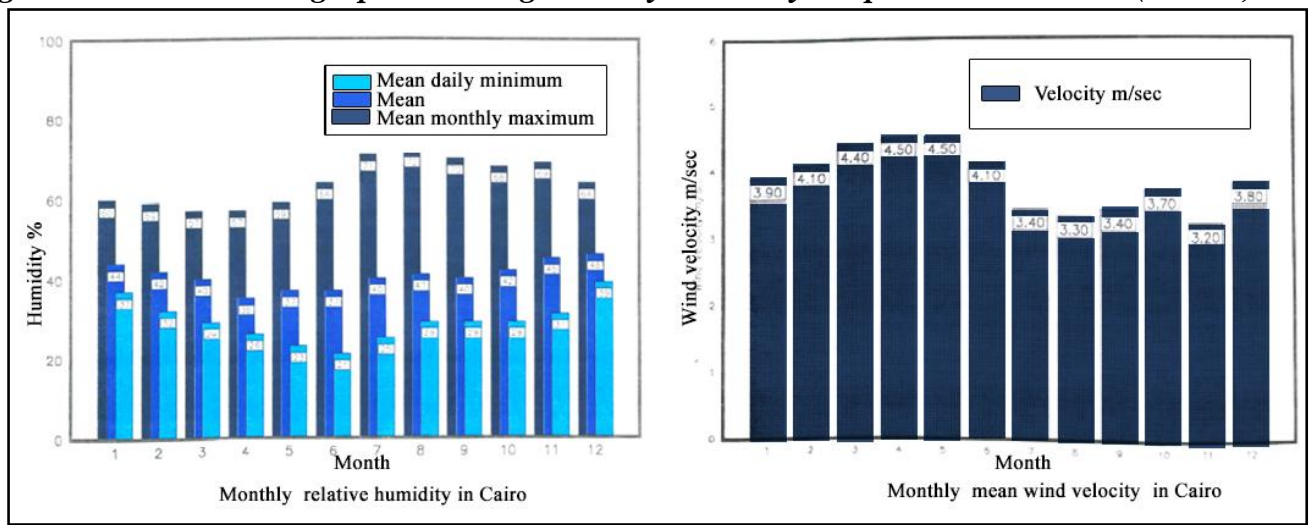

Figure 7 Cairo climatic graphs showing the monthly relative humidity and the wind velocity. Source: (NAGA, 1990)

\subsection{Zeinb Khatoun description}

The house is designed as an introverted plan where all the functional spaces are placed around a central courtyard. It consists of two blocks; a two storey and three stories masses. Two different entrances are designed to separate the visitors and the resident to match the privacy concept. The main architectural features are described in the following:

It has two main elevations as it is located on an intersection and the other two sides are attached to neighbor buildings. These elevations are made of stone and wide openings. Te first one features the main entrance, lower and upper openings that are covered by Mashrabeya. The second one is relatively small and it is facing northwest.(Figure 8)

The main entrance is an oblique one with wooden beam ceiling. A rectangular room with wood ceiling is located to the right of the entrance that contains a passage leading directly to the main courtyard. The side entrance is followed by rectangular corridor covered with vaults.Main square courtyard is created according privacy purposes and is used as a microclimate that helps regulating indoor temperature and providing natural ventilation and lighting. It also used to have a fountain which is now buried under its pavement. A constant airflow is created between the main courtyard and the secondary 
one, reducing the temperature and creating pressure difference. The courtyard is inclined $17^{\circ}$ to the northeast with a shaded area representing $82 \%$ and $77 \%$ of its floors and walls. The house consists of four different wings where most of the living spaces; the winter hall and summer hall, are placed on the South West and the North West wings of the courtyard. Facing the northeast, the third wing exists compromising the main entrance, above which there is a teraace faces the summer winds. A few secondary rooms form the fourth wing facing the northeast.
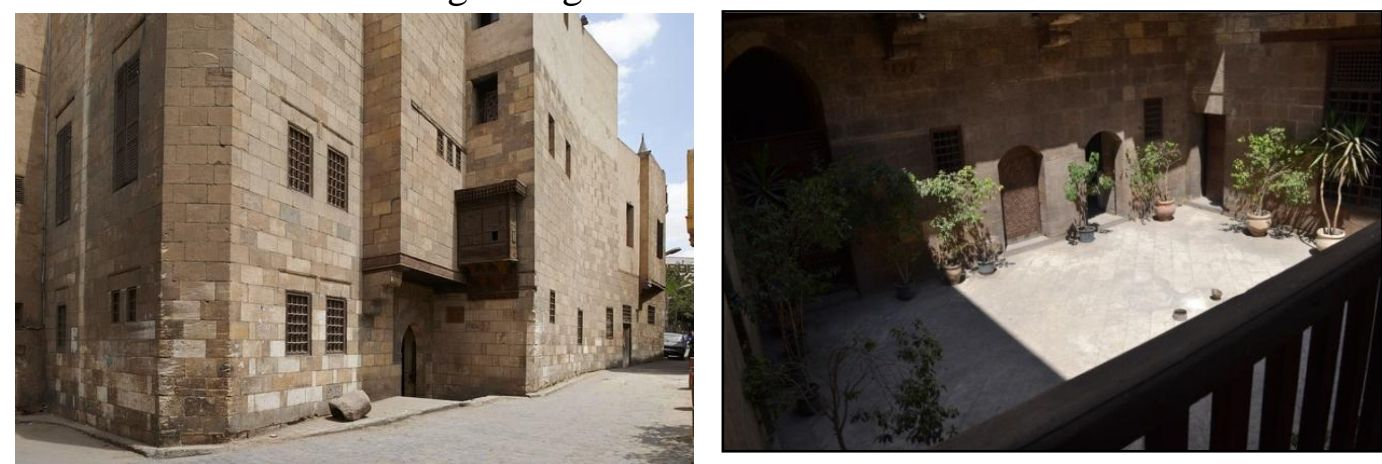

Figure 8 The main elevations of the case study house; and the main courtyard of the house. Source: http://archnet.org/sites/4404/media_contents/15258

In the north side of the courtyard, a Maqaad exists to improve natural ventilation for its users. On the first floor of the house, a large hall that consists of a squared space named Durqaa flanked by iwans covered by wooden beams serves as heat insulators. It has a Shokheshakha in the middle that provides natural ventilation and lighting to the space. Different Mashrabeyas are overlooking the courtyard and surmounted by Qamareys surface southward to decrease the amount of sun radiation. In addition, the warm air is directed outside the house through the upper openings which ensure a stack effect and good lighting design reaching almost every internal space. The southeast wing is located between the three courtyards and compromises the reception hall and its ground floor. The arrangement of the reception hall between the main courtyard and the service one generates a constant airflow.Three rectangular rooms cover the bath having a khoshakha in its ceiling providing lighting and ventilation. A Malqaf is located on the roof catching the cool air and directing it into the different spaces to ensure a steady airflow that will be introduced in details.(Figure 9)
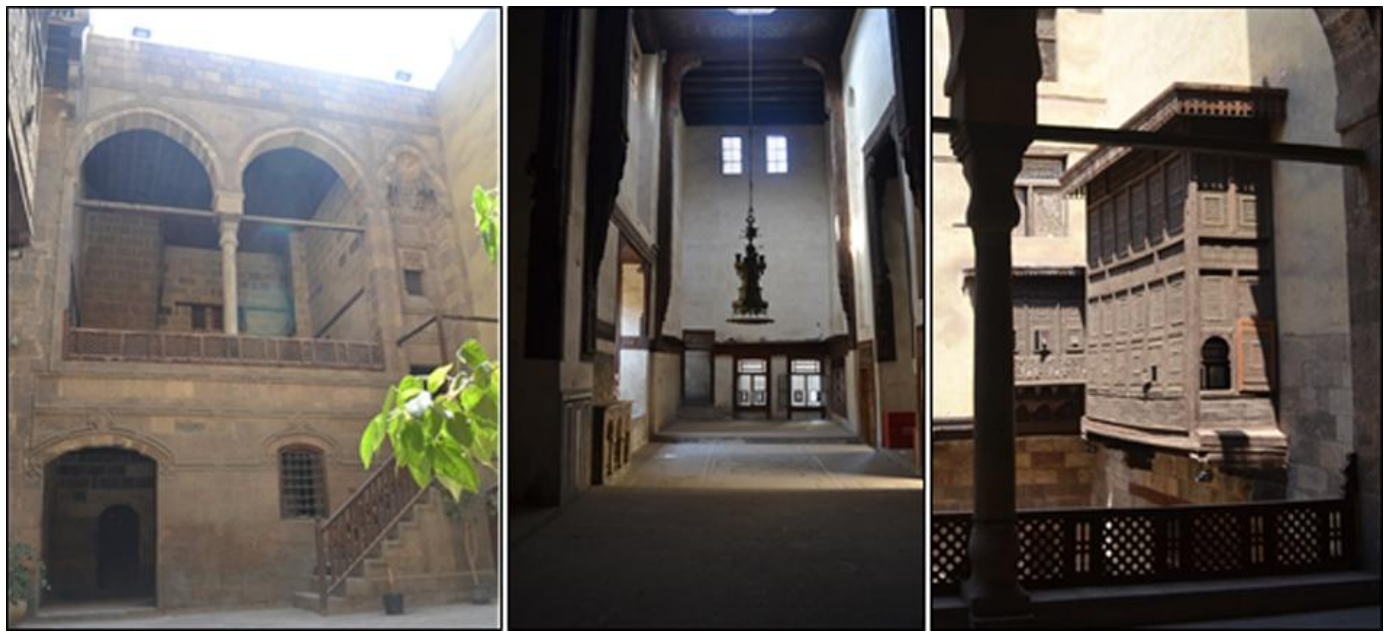
Figure 9 The first photo is for the Maqaad located facing north side, in the middle is the Qaa which is the reception hall of the house, the photo is the view from the Maqaad showing the different Mashrabeya looking overlooking the courtyard. Source: researcher

\subsection{Natural ventilation principle in the case study}

The house is designed to combine two main natural ventilation drivers; wind effect and stack effect which improve the natural ventilation. The wind ventilation is achieved through different pressure zones created on the house envelope. This helps driving the air into the house through openings located in the windward side and drive it out through the leeward side. The house design permits a good rate of cross ventilation through each floor, openings are designed to take advantages of the upcoming wind and redirect the wind inside the different zones of the house. They are inclined by $20^{\circ}$ to the wind direction which enhance the ventilation rate. Moreover, an air shaft is placed in the south east wing catching the wind and orienting it to the house. The three courtyards are located in order to distribute the wind to different interior zones.

Stack effect is achieved through the different courtyards design where, there is a difference in density between the air inside and outside due to the temperature difference. The cold air is captured and directed into the courtyard through openings or air shaft thus, the hot air rises up which reduce the inside temperature. The following picture shows the pressure contours created by the courtyard of Zeinb Khatoun. As shown, the pressure is decreasing as the air rises up due to the temperature difference ensuring stack effect.
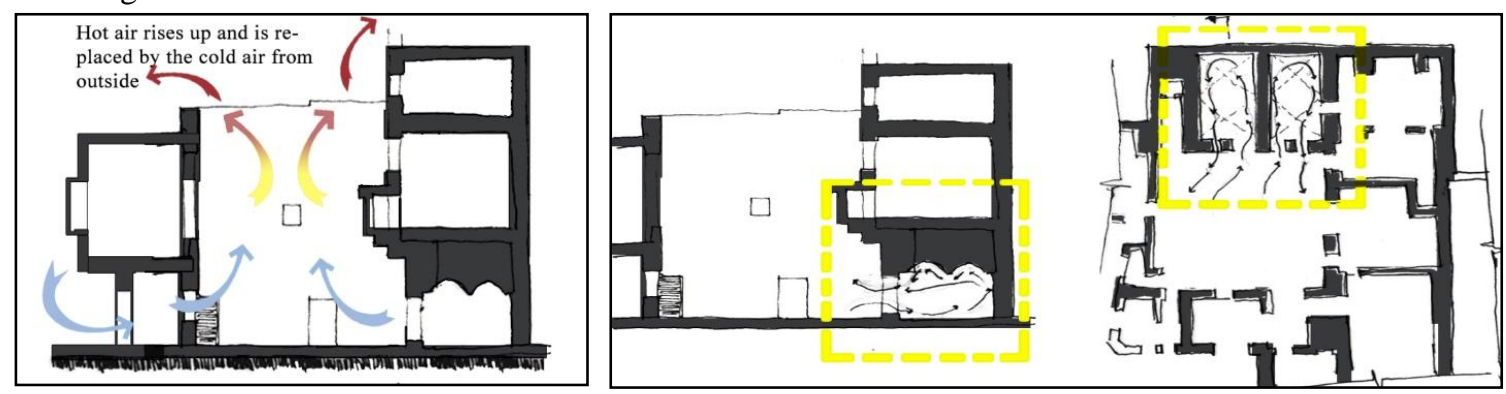

Figure10 Stack effect, single sided and cross ventilation in the courtyard house. Source: researcher Cross ventilation by wind driven airflow is achievable in the case study house. The design permits the airflow to enter from one opening (in the windward wall) and passes through the interior space to leave from another opening (in the leeward wall). This can grant stable airflow across most of the interior spaces. Adding courtyard in the middle of the house, allows more airflow to be diverged, thus achieves efficient cross ventilation. For cross ventilation efficiency, each room has width less than five times the height. This ensures a better cross ventilation in different zones. The following figure representing ground and first floor plan of the case study house, shows the air crossing through different zones achieving cross ventilation technique. (Figure 10)

\section{Natural ventilation technical parameters}

There are many technical parameters enhancing passive ventilation that were implemented in the case study house. These elements can be classified under architectural level as they are based on the design. The courtyard as a system is considered of the main techniques that has different characteristics. These characteristics such as the orientation, the courtyard envelope (openings characteristics and the wall enclosure of the courtyard), 
the thermal mass, ventilation inducers used, the internal planning, landscape elements and more are analyzed in the following section.

\section{Courtyard orientation}

Zeinb Khatoun's house is composed of three courtyards. The main courtyard is located at the center where it is surrounded by all other rooms. It is inclined by $17^{\circ}$ EastNorth axis which is acceptable for natural ventilation. However, the optimum angle for best air circulation is $45^{\circ}$ and $90^{\circ}$ for maximum airflow. Most of the opening's designs, in courtyard, are oriented with respect to the prevailing summer breezes; north- south orientation and east orientation. This orientation of courtyards and its openings achieves to get maximum exposure to wind flow during night with a minimal exposure to the afternoon sun.(Figure11)

\section{Courtyard envelope}

The main courtyard envelope design is composed of two main elements. They are classified as the courtyard openings design with different characteristics including their size, position, number and type and the wall enclosure surrounding the courtyard. The next section will analyze these two factors for enhancing better ventilation.The courtyard compromises different openings designs that differ in their sizes, area, orientation, type and their ratio to each façade. The maximum ratio of openings is in North façade, which is $33 \%$. However, the minimum ratio is in the eastern façade, which is $2.82 \%$. The south façade compromises $22.28 \%$ openings ratio and the west façade $20 \%$ openings ratio.

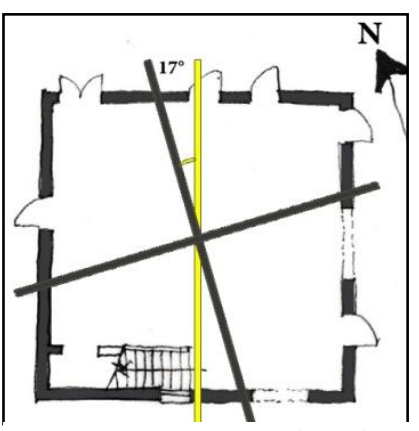

Figure 11 Courtyard inclined $17^{\circ}$ on the $\mathrm{N}-\mathrm{S}$ axis. source: researcher

The openings size controls the ventilation rate and the air velocity. For achieving better ventilation rate, this requires larger inlet and outlet for openings. The biggest size of opening is locating in the north facing side of the courtyard. In the ground floor, there are three openings; two doors with dimension $1.5 \times 2.6 \mathrm{~m}$ (the main entrance to the courtyard) $1.86 \times 1 \mathrm{~m}$ (side door that lead to a service room) and one window that overlook the lobby of the entrance with dimension $1 \times 1.2 \mathrm{~m}$. The first floor has one main opening that lead to the maqaad $5.6 \times 4.4 \mathrm{~m}$. The other side facing the wind and considered as an inlet is the west elevation of the courtyard. It has one large window covered with mashrabeya to avoid the direct heat from the sun $(3.2 \times 3.5 \mathrm{~m})$ another opening smaller in size $(2.8 \times 2.2 \mathrm{~m})$. Smaller windows are location in the third level $(1.5 \times 0.8 \mathrm{~m})$ and two doors at the ground level $(0.9 \times 2.2 \mathrm{~m})$. These two elevations are considered the most effective for ventilation. They are facing the wind direction (North- 
west) and they compromise the main living space of the house. They are characterized by large inlet and smaller outlet which allow better air flow inside these spaces.

As for openings orientation, the best orientation is to be facing North West in order to catch the prevailing wind and redirect it into the space. This is achievable in the courtyard design as the largest windows are oriented to the wind direction. For the leeward sides, that is not in the wind direction, contain fewer openings such for the east facing side that has only two openings with total area $3.2 \mathrm{~m} 2$ (.Figure 12)

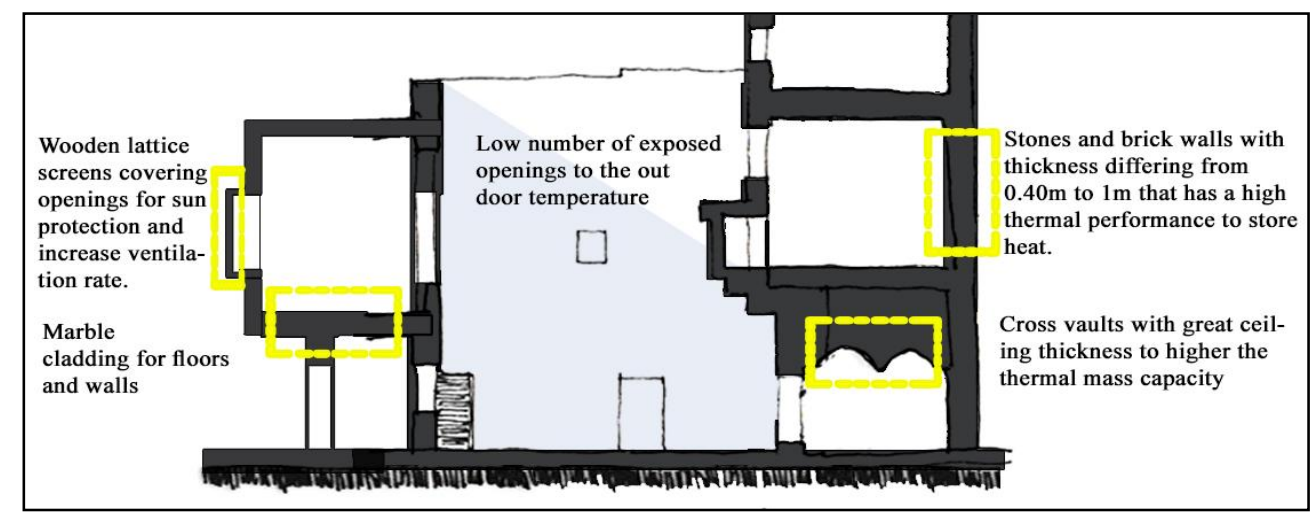

Figure 13Thermal performance analysis of the case study house's courtyard.Source: researcher

\section{Wall enclosure}

The courtyard design assures a high degree of enclosure which increases the shaded area of the courtyard during the summer time. The total area of courtyard surrounding walls is $478.90 \mathrm{~m} 2$. Ground floor area of the courtyard is $89.77 \mathrm{~m} 2$; the top surface of the courtyard area is $80.22 \mathrm{~m} 2$. The total enclosure is $5.96 \mathrm{~m} 2$. With these areas, the amount of solar radiation is high during the summer and the west façade has the most exposure to sun at $15 \mathrm{pm}$. On the 21th on December, the south façade receives maximum amout of solar radiation at $12 \mathrm{pm}$. On the 21 june, the courtyard receives the smallest amount of radiation due to high ratio of projections and the high degree of enclosure. The courtyard width to height ratio is 1:58 thus, delaying the sun rays to enter by 1 to 2 hours in summer and winter (Wazeri, 2013).

\section{Courtyard Thermal mass}

Zeinb Khatoun's courtyard has a high thermal mass. This has a direct effect on the natural ventilation specially night ventilation. The highest thermal mass is considered the ground floor according to its space volume ratio and the fact that some spaces have heavy stone roofs of cross vaults. Marble floor and marble wall cladding covers the summer hall with $10.6 \mathrm{~m}$ ceiling height and covers the walls to $1.2 \mathrm{~m}$ height. The winter hall which is $8.5 \mathrm{~m}$ height has three windows facing southwest and having buttresses aside with heavy thermal mass. No openings are exposed to the exterior ambient air in neither the summer hall nor the winter hall.

Towspaces have light thermal mass; the first one is the loggi that is located in the first floor overlooking the courtyard and the second one is a rooftop wing attached to a small room. With high thermal mass, the house is affected by night ventilation. During winter, the thermal mass stores the heat all daytime and by natural ventilation the heat is dissipated at night to keep the house warm. This phenomenon is essential to maximize the heat transmittance during night and minimizing it during the day. (Figure 13)

\section{Natural ventilation inducers}


The Mashrabeya is considered as a main element in the courtyard house. It has an effective role in assuring high privacy level, permitting an adequate daylight to enter without the uncomfortable reflected glare, reducing the air temperature entering, and increasing the humidity level as it is made up of wood that absorbs, retains and dissipates water as the air passes through. Two main kinds of mashrabeya were used in the case study house. The wider one is $0.16 \times 0.16 \times 0.025 \mathrm{~m}$ with solid to void ratio 0.34 . It covers almost $34 \%$ the total area of the window with a shades transmittance value 0.65 . The narrow one is $0.012 \times 0.012 \times 0.012 \mathrm{~m}$ with 0.5 solid to void ratio and shades transmittance 0.5. It covers almost $50 \%$ of the total area of the window (Amr Bagneid, August 2-4, 2006). The wider grid improves the air flow and distributes the air inside each space. The narrow grid covers a large are of openings which makes it also effective for ventilation.

The courtyard design compromises different envelope projection thus, improving its efficiency. They are classified under horizontal and vertical projections. The horizontal projections as shading devices located on almost most of the openings such as mashrabeya. Other horizontal shades are used to integrate the solar and air movement control as the courtyard envelope. (Figure 14-15)

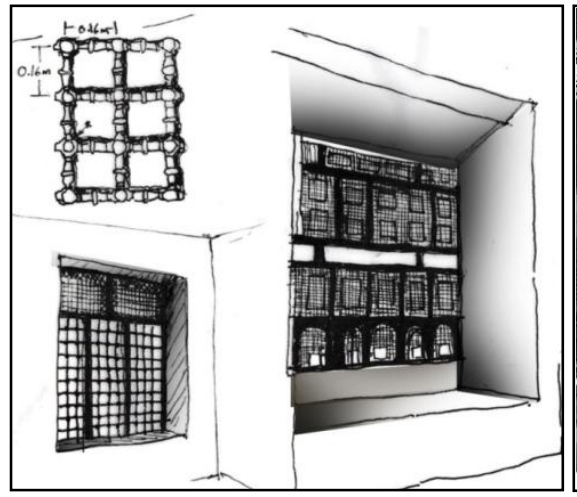

Figure 14 nterior view of wide and narrow mashrabeya of zeinb khatoun. Source: researcher

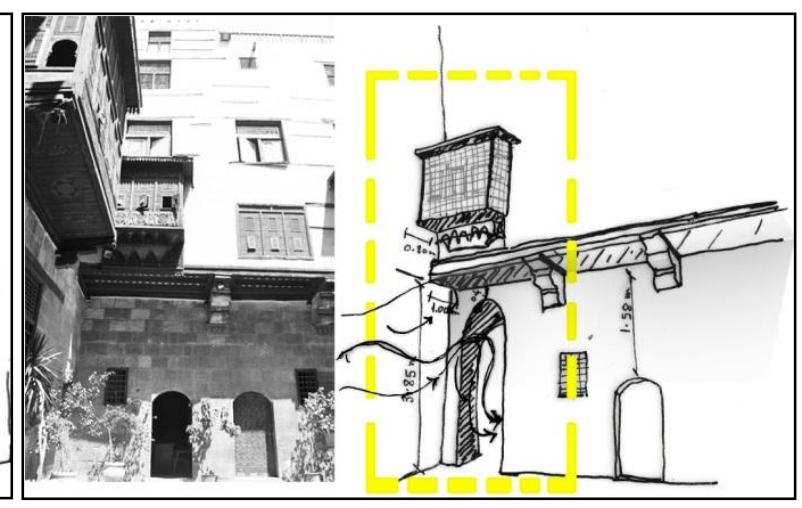

Figure 15 Horizontal shading elements to redirect the air flow inside the house. Source: researcher.

\section{Wind tower (Shokhshekha)}

One of the main elements of ventilation inducers that have a great effect for the indoor ventilation is the Shokhsekha located above the ceiling of the summer hall. It is octagonal in shape and is the highest mass of the house. It works on inducing negative pressure and provides suction effect to draw the air out. More air flow can be introduced through the house by collecting and extracting air at high levels by greater pressure difference. (Figure 16)
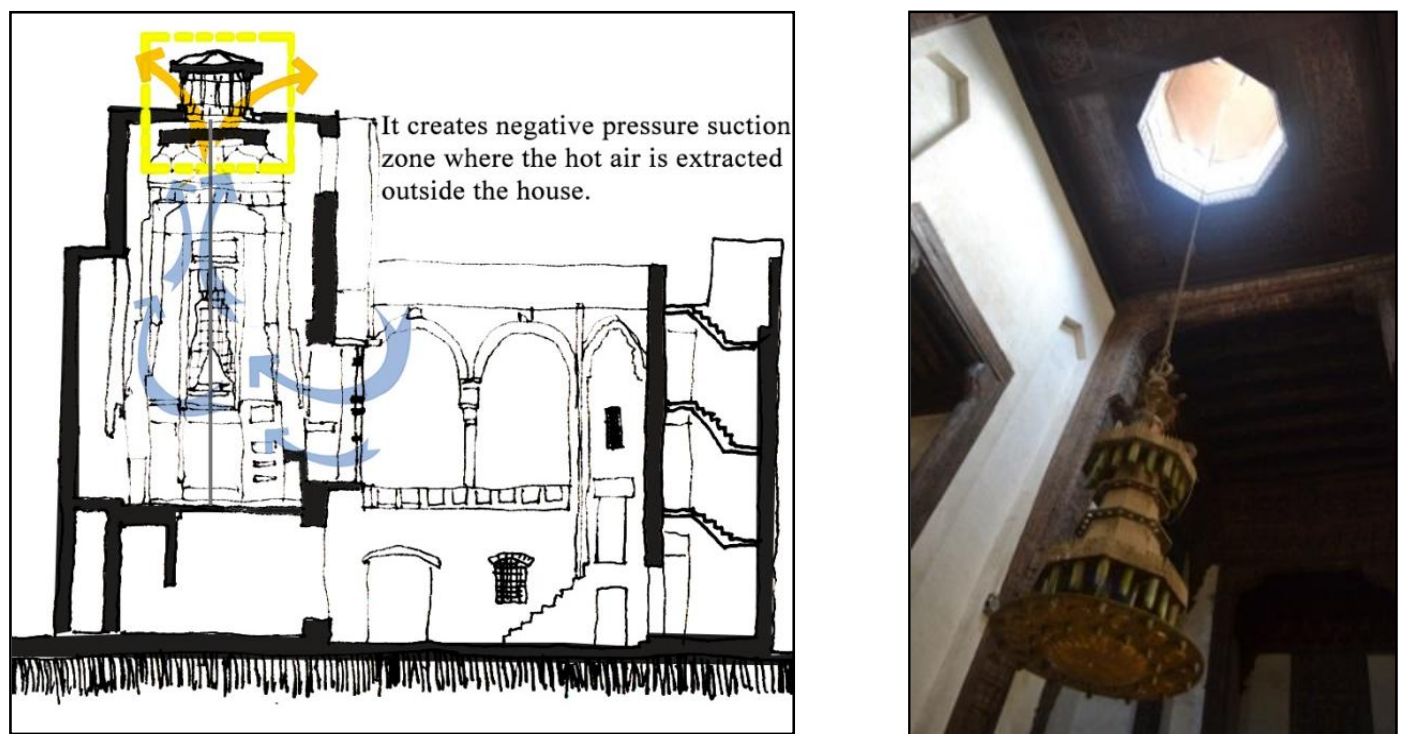


\section{Internal planning around the courtyard}

The plan design helps in improving the air flow within different spaces. The ground floor is not an open plan unlike the first floor plan. It is consisted of open spaces with no furniture blocking the air flow. All of the spaces are surrounded the inner courtyard which gives the opportunity for all spaces to be well ventilated. Locating the tall masses in the west wing to avoid the direct sun radiation thus, changing the internal pressure to provide more air circulation. In addition, they act as air catching to redirect the air flow to the internal spaces.(Figure 17)

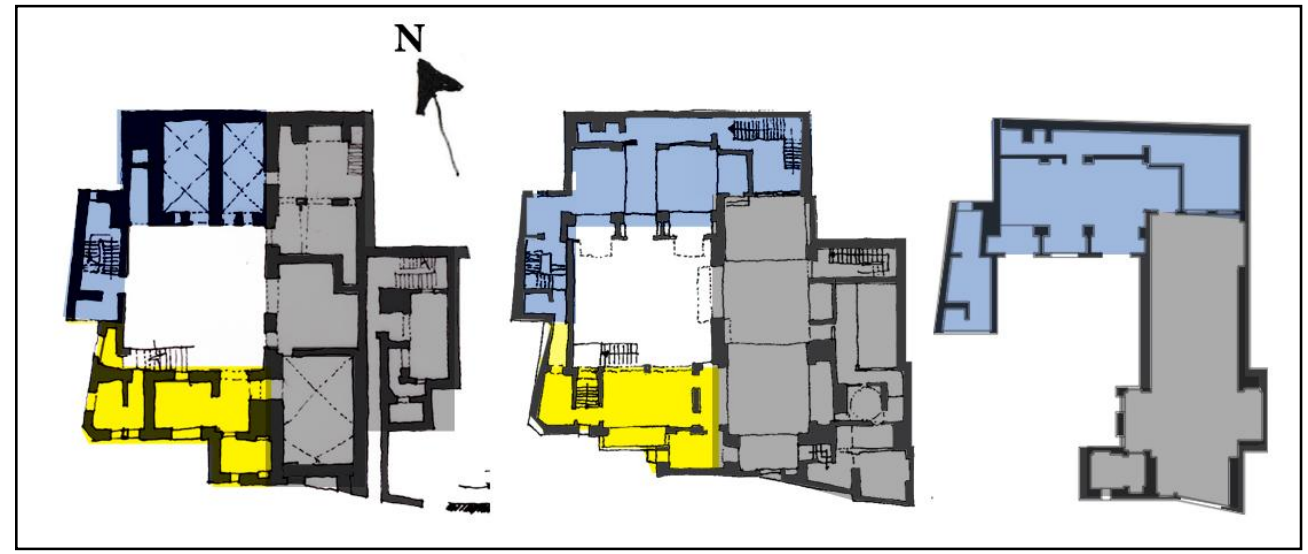

Figure 17: Room arrangement around the courtyard Source: researcher

\section{Landscape elements}

The house used to have a garden in the main courtyard but it no longer exists. The main courtyard has some different plants such as Ficus Benjamina and yucca but they don't have an effective role for enhancing ventilation. They have small leaves and they are small in sides which preventing them to create high shaded area. There used to be another garden at the secondary court but it has been demolished(.Figure18)
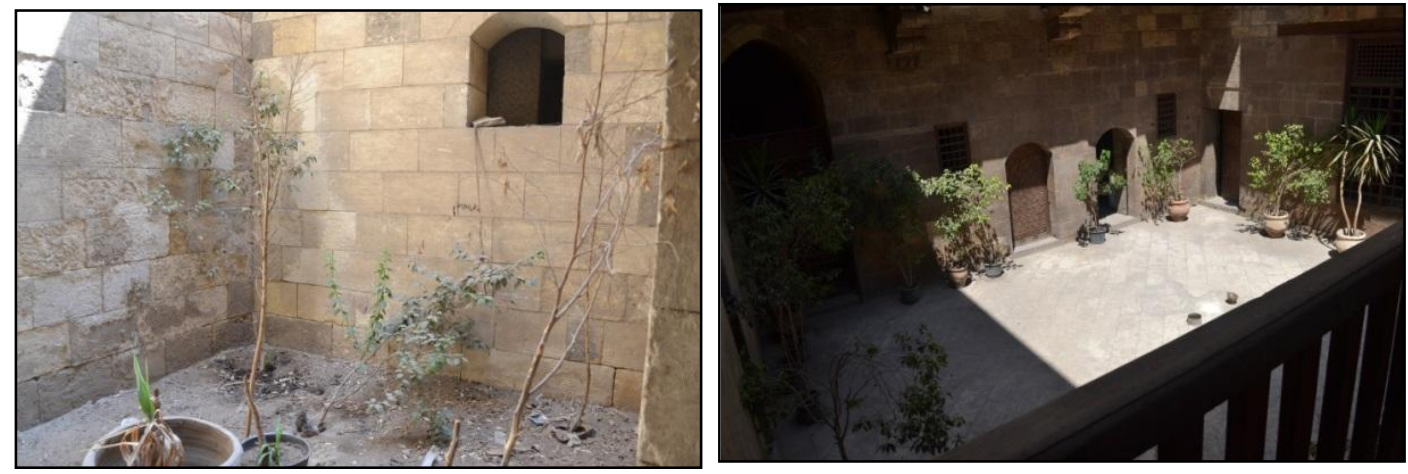

Figure 18Backyard and main courtyard and the existing andscape. Source: researcher

\section{Conclusion}

The courtyard house typology has been presented through history in Egypt. The history, social, cultural and architectural aspects of courtyard houses has been discussed briefly. It has clarified the difference of each period which has influenced the courtyard design. The second part discussed the passive cooling elements in general implemented in hot arid region and allocated mainly the theories and strategies for passive ventilation 
and its importance to achieve thermal comfort for users, thermal control thus reduction in energy used in cooling and improving air quality by removing odors and pollutant. It also showed the different theories of natural ventilation; the driving force, the principle used and the characteristic element that can be used.

It was conducted that the best orientation in hot arid climate is the east west axis to avoid over heating by the sun and an inclination by angle $15-45^{\circ}$ is more adequate for ventilation. For courtyard envelope design, placing inlet facing the wind direction perpendicular or oblique, in the center of the wall where the pressure is the highest, increases the amount and speed of air entering the building. Louvered and screened openings are preferably used to direct the wind to the desired space, although it can help increasing the wind speed. In addition, horizontal and vertical projections might be added if the inlet is not facing the wind direction to induce high pressure zone. The outlet is best to be placed in wind shadow (low pressure zone)or to be exposed to an eddy. Moreover, stack ventilation can take place if the outlet is placed at a higher level near the ceiling. For cross ventilation effectiveness, the size of the inlet and outlet should be maximized for maximize ventilation rate. However, higher wind speed can be created when decreasing the inlet size and increasing the outlet. Any ventilation inducer is highly recommended to catch the wind and redirect it into different interior zones. Finally, adding landscape and water elements in the courtyard has a significant effect on the airflow as it helps in evaporation cooling thus decreasing the temperature and provide lower pressure so more air flow is provided.

\section{List of referneces}

- Abdulbasit Almhafdy, N. I. (September 2013). Analysis of the Courtyard Functions and its Design Variants in the Malysians hospitals. Asia Pacific International Conference on Environment-Behaviour Studies (p. 12). London: University of Westminster, London,.

- Ahmed S. Muhaisen, M. B. (january 2005). Effect of courtyard proportions on solar heat gain and energy requirement in temperate climate of Rome. Nottingham,UK: El Sevier, Building and Environment 41 (2006) 245-253.

- Ahmed, M. A. (2012). Natural Ventilation Techniques as a Base for Environmental Passive Architecture. Cairo: Ain Shams University.

- Al-Shaali, R. K. (2006). Tools for Natural Ventilation in Architecture. Los Angeles: UNIVERSITY OF CALIFORNIA.

- Amr Bagneid, J. H. (August 2-4, 2006). A CALIBRATED COMPUTER MODEL FOR THE THERMAL SIMULATION OF COURTYARD MICROCLIMATES. Cambridge: IBPSA-USA Conference SimBuild 2006.

- Authority, L. T. (2003). Electronic Road Pricing. Retrieved April 17, 2012, from http://www.lta.gov.sg/content/lta/en/motoring/erp_.html

- Burton, E., \& Mitchell, L. (2006). Inclusive Urban Design: Streets for Life. Oxford: Elsevier/Architectural Press.

- Camille Allocca, Q. C. (2003). Design analysis of single-sided natural ventilation. USA: Energy and Buildings.

- Cervero, R. (1998). The transit metropolis: a global inquiry. Washington, D.C.: Island Press.

- shapes on solar heatgains and energy efficiency according to different climatic regionsEnes. Turkey : ELSEVIER.

- Feng Liguang, W. Z. (2009). Evaluation on the Effect of Car Use Restriction Measures in beijing. China: Beijing Municipal Committee of Transport.

- Fessl, T. (2010). Urban Space and Design for the Pedestrians. Austrian Road Safety Board.

- Force, P. I. (1994). Walk Boston, A Pedestrian Perspective on the Central Artery Project. Boston: Pedestrian Issues Task Force. 
- Hanna, G. B. (2013). Sustainable Energy Potential in the Egyptian Residential Sector. Egypt: David publishing.

- Hartmut Topp, T. P. (1994). Car-free city centres. Transportation, 231-247.

- Khalid Setaih, Bhzad Sidawi and Neveen Hamza. (August 2014). CFD MODELING AS A TOOL FOR ASSESSING OUTDOOR THERMAL COMFORT CONDITIONS IN URBAN SETTINGS IN HOT ARID CLIMATES. Tyne,UK: Journal of Information Technology in Construction (ITCON).

- Kleiven, T. (2003). Natural Ventilation in Buildings :Architectural concepts, consequences and possibilities. Norweay: Norwegian University of Science and Technology.

- KumKum, D., \& Israr, A. (2007). Carpooling: A Step To Reduce Congestion (A Case Study of Delhi). Delhi: International Association of Engineers.

- Litman, T. (2012). Parking Management:Strategies, Evaluation and Planning. Australia: Victoria Transport Policy Institute.

- Litman, T. (2012). Road Pricing. Victoria: Victoria Transport Policy Institute.

- MILLARD, A. (2005). Car-Sharing:Where and How It Succeeds. WASHINGTON, D.C.: Transportation Research board.

- Mohamed el Nabawi, D. N. (2013 August 26/28). Use and evaluation of the envi-met model for two different urban forms in Cairo, Egypt: Measurments and simulation. Chambery, France: IBPSA.

- Morrish, G. (2009). Street Design Guidelines. Landcom.

- NAGA, M. M. (1990). NATURAL VENTILATION AND COOLING BY EV APORA TION IN HOT ·ARID CLIMATES. Leeds: THE UNIVERSITY OF LEEDS.

- Naga, M. M. (1990). Ventilation and cooling by evaporation in hot arid climates. University of LEEDS.

- Nasser A Al-Hemiddi, K. A.-S. (2001). The effect of a ventilated interior courtyard on the thermal performance of a house in a hot-arid region. Riyadh, Saudi Arabia.: EL SEVIER, Renewable Energy, Volume 24, Issues 3-4, November 2001, Pages 581-595.

- Osman, M. M. (2011). EVALUATING AND ENHANCING DESIGN FOR NATURAL VENTILATION IN WALK-UP PUBLIC HOUSING BLOCKS IN THE EGYPTIAN DESERT CLIMATIC DESIGN REGION. Scotland: Dundee School of Architecture.

- Paul Gut, D. A. (1993). Climate responsive building. St. Gallen, Switzerland: SKAT.

- Reid Ewing, S. H. (2006). Identifying and Measuring Urban Design Qualities Related to Walkability. Journal of Physical Activity and Health.

- Shaftoe, H. (2008). Convivial urban spaces: creating effective public places. London: Earthscan.

- Shrivastava, P., \& O'Mahony, M. (2009). Modeling an Integrated Public Transportation System - a case study in Dublin, Ireland. Dublin: European Transport.

- TFL. (2009). 8 Technical Guidance: Street Furniture. London: Transport For London.

- Transportation, U. D. (2009). SAS Output. Retrieved November 28, 2012, from SAS Output: http://nhts.ornl.gov/tables09/ae/work/Job24716.html

- Utsch, E. (2007). Congestion Pricing - Advantages and Disadvantages Shown at the Example of London. . Istanbul: Urban Planning and Policy.

- Wael Sheta, S. S. (2010). A Building Simulation Sustainability Analysis to Assess Dwellings in a New Cairo Development. New York, USA: IBPSA.

- Wazeri, Y. H. (2013). COMPARATIVE STUDY BETWEEN THREE COURTYARDS OF TRADITIONAL HOUSES IN ISLAMIC CAIRO. Journal of Islamic Architecture.

- West, A. W. (October 2000). AN EXPLORATION OF THE NATURAL VENTILATION STRATEGIES AT THE WORLD TRADE CENTER AMSTERDAM. Blacksburg, Virginia: Faculty of Virginia Polytechnic Institute and State University.

- Yahya Lavafpour, M. S. (2011). Passive Low Energy Architecture in Hot and Dry Climate. Bangi: Australian Journal of Basic and Applied Sciences 5(8): 757-765. 
